to each of which he has made noteworthy contributions. In the field of protein chemistry he enlarged our knowledge of the phosphoric acid esters present in casein and of the serum glycoproteins; and latterly with his colleague, I. W. Rowlands, he has turned his attention with outstanding success to the important glycoprotein, gonadotrophin of pregnant mares' serum, a problem of great veterinary interest. During his stay in South Africa, Dr. Rimington worked on the constituents of plants poisonous to stock and from this made an incursion with $J$. I. Quin into the photosensitization of animals by phylloerythrin. With P. J. Fourie he discovered the first living cases of congenital porphyria in animals, and this has led to numerous contributions to the porphyrin field of pigment metabolism, on which he is an acknowledged authority. Without doubt Dr. Rimington will be received with welcome at University College Hospital Medical School, for his capacity for collaboration has been a valuable and invariable asset.

\section{Geological Society Awards}

The Council of the Geological Society has made the following awards: Wollaston Medal to Prof. 0 . T. Jones, emeritus professor of geology in the University of Cambridge, for outstanding contributions to knowledge concerning the stratigraphy of Lower Palæozoic sedimentary rocks of Wales; Murchison Medal to Dr. W. Campbell Smith, keeper of minerals in the British Museum (Natural History), for his work on petrology and mineralogy, and his long service as secretary to the Society; Lyell Medal to Dr. L. F. Spath, of the Geological Department of the British Museum (Natural History), who is the foremost expert on the Ammonoidea and on the classification and evolution of the Cephalopoda; Bigsby Medal to Prof. L. R. Wager, of the University of Durham, for his outstanding researches, mainly in petrology, on East Greenland, the Sikkim Himalaya and the north of England; Prestwich Medal to Mr. A. S. Kennard, for his studies of Pleistocene faunas particularly of the non-marine mollusca; Wollaston Fund to Dr. D. R. Grantham, for his work on the Geological Surveys of Tanganyika and British Guiana, especially in the field of mining geology; Murchison Fund to Dr. W. A. Deer, for his researches on rock-forming minerals and petrology, especially of Scottish rocks; and his contribution to the description of the layered intrusion at Kangerdlugssuak in Greenland; one moiety of the Lyell Fund to Mr. A. H. Taitt, of the Anglo-Iranian Oil Company, Ltd., for his work on the exploration for oil in Great Britain, especially on the Nottinghamshire oilfield; another moiety of the Lyell Fund to Dr. F. B. A. Welch, of the Geological Survey of Great Britain, for his additions to our knowledge of the geology of south-west England, both above and below the Mesozoic unconformity, especially in relation to the complicated structures of the Mendips.

\section{Display and Bower Building in Bower Birds}

THE annual cycle of display and bower building by Ptilinorhynchus violaceus Vieill, the satin bower bird, was discussed in Nature, 153, 685 (June 3, 1944), by A. J. Marshall. He stated that this cycle is possibly due to the effect of increasing light and that stimuli from the bower act "through the anterior pituitary" upon the gonads. The selection of coloured decorations by the male matches the epigamic colours of the female and may "serve the function of exciting himself by their resemblance to female colours". It is regrettable that Marshall omitted reference to published work on these lines when mentioning investigations carried out during 1939-41. In "A Contribution to the Biology of the Satin Bower-bird" (Australian Zoologist, 10, 95; 1941), E. Nubling considerably antedates Marshall's conclusions and in some points differs from them. Nubling found that the bower building is not associated with increasing light, for during 1922-26 he found new bowers principally erected in May and June during decreasing light, and states that in such circumstances the whole proceeding of courtship and nidification fall into the period of decreasing light. Regarding the part played by the pituitary body, Nubling wrote (loc. cit., 119), "the role of the pituitary in connection with such sexual manifestations as posturing during display or ceremonial is thus apparently a factor of outstanding importance", and he quoted the opinion of F. H. A. Marshall (1929) that sexual posturing in birds exercises a stimulating influence upon the anterior lobe of the pituitary.

Nubling discussed the selection of colours very fully in 1941, and so long ago as 1924 had submitted conclusions which were published by Dr. Casey A. Wood (Amer. J. Ophthal., 8, 120; 1925), as follows : "Nubling's preliminary experiments made with colored disks . . I I shall now report in his own words. '1. Violet, indigo, blue. Any of these colours is collected by these birds, as well as any hue or tint thereof, without any discrimination. ...2. All the other colours collected correspond to those of the plumage, bill, legs, etc., of the immature male and the fermale, whose plumage is identical. On this I am almost positive, and many comparisons made, using Ridgway's Color Standards for the purpose, have borne out my contention'". Wood points out that the irides of the female are of an even stronger blue than those of her mate. In 1941 Nubling wrote again (loc. cit., 117) that the "decorations are not collected for the sake of their brightness, but for their colours ... they represent the insignia, so to speak, of his female mate. The presence at the bower of objects bearing her colours is then not so much for the purpose of attracting the female, but for his own stimulation; they act on him in the way of an aphrodisiac". Nubling compared the exciting colours with Ridgway's 1912 Colour Guide : it seems that the "lemon-yellow" mentioned by A. J. Marshall is so masked by grey that the resultant effect is erroneously described as lemon-yellow; it corresponds to Ridgway's "deep greyish olive", the colour of the upper surface of the female. This is produced by a structural effect, combined with superposed yellow lipochrome, the black plumage of the male giving a blue structural effect.

\section{Health Problems in War-time}

Brigadier-General J. S. Simmons (Brit. Med. J., 572 , Oct. 28, 1944), speaking at the seventy-third annual convention of the American Health Association at New York on health problems during the past year or so in Italy, Sicily and north-west Europe, said that the public health programme is being carried out by a very small number of American and British medical officers and that it was necessary to rely upon local medical men. The greatest problems so far had been typhoid fever, dysentery, typhus fever, smallpox, malaria, venereal disease and scabies. In Italy and north-west Europe the incidence of typhoid 
and paratyphoid fever rose after the military operations, but outbreaks had been limited to relatively few communities. The peak was reached in January 1944, when more than a million new cases were reported; but the outbreak was controlled so quickly that only 39 cases were reported during the last week of February 1944. Typhus had not yet been a problem in north-west Europe. Two outbreaks of smallpox had occurred in Italy, but none in north-west Europe. In February 1944, measures for the control of malaria were inaugurated in south and central Italy.

The United States War Department announced, on October 4, that tetanus had been virtually eliminated from the United States Armed Forces by compulsory immunization of all officers and men. No case had been reported among completely immunized troops, but a handful of cases had occurred when immunization had not been complete. Up to September 15, 1944, no cases had occurred in the United States Navy, which also requires cotnpulsory immunization. Brigadier-General R. W. Bliss, assistant surgeon general, United States Army, said that, during a recent tour of the Pacific War theatre, he did not see one mosquito or fly. "When we first took over the Pacific Islands," he said, "there were clouds of insects everywhere, actually making it difficult to see. To-day, if we locate one mosquito, we consider it comparable to finding a four-leaf clover. To me, that's the outstanding achievement of medical science in this war." There were no malaria-carrying mosquitoes in Saipan, but there were species which carried dengue fever. After a few weeks of insect control, dengue fever, of which there had been a great many cases, practically disappeared. Medical sanitary companies divided the island into squares and drained and filled in swamps constantly. "The amazing D.D.T. insecticide, which did such a wonderful job in controlling typhus in Naples, was sprayed by hand and by planes."

\section{Birds in Agriculture}

DeFinite evidence on bird behaviour is ever valuable, especially as regards agriculture, and Mr. A. Roebuck, of the Midland Agricultural College, has done well to put on record in the form of a leaflet five cases in which birds gave help to the farmer ("Birds in Agriculture." By A. Roebuck. Midland Agricultural College, Sutton Bonington). Rooks, lapwings and blackheaded gulls were the species that in these instances did much good work with regard to wireworms (Agriotes obscurus), dungbeetles (Aphodius pinetarius and $A$. inquinatus), leatherjackets (Tipula paludosa) and cutworms (Agrotis segetum). Of course, it has long been known that these birds take such agricultural pests, but here we have facts lucidly set forth that show how useful they are in the economy of the farm.

\section{Empiricism and Descartes' Dream Situation}

THE problem of determining the status of empirical propositions continues to exercise the minds and engross the attention of philosophers more than any other philosophical problem. The easy solutions of the logical positivists are being slowly torn to pieces by the more leisurely consideration of philosophers who, while sympathetic towards the general attempt to distinguish among propositions between the empirical sheep and the metaphysical goats, are yet suspicious of the ways of doing it. The attempt to find an empirical content for all genuine propositions gives rise to a number of problems. In the seventeenth century, Descartes had expressed the view that as the senses sometimes deceive, they might do so always. Therefore he concluded that he might be dreaming, no matter how wide awake he seemed to himself to be. Can one maintain this position without self-contradiction?

In a paper "On the Relation of some Empirical Propositions to their Evidence" (Mind, Oct. 1944), Mr. C. Lewy discusses whether it is self-contradictory to say that "I have all the evidence which I do have for saying that I am not now dreaming, and however many tests I may make in the future, they will all confirm this evidence, but I am now dreaming" (p. 289). The paper is long, subtle and difficult to follow. The point of the discussion, when reached, consists in the author's showing that the first part of the statement quoted makes the demand that all the evidence that turns up should be positive, whereas the second part demands at least one piece of negative evidence. There could not be a situation which fulfilled these two conditions. The author concludes not, as might be expected, that the statement is self-contradictory, but that to the question whether it is or not, no answer is possible.

\section{Fixing Confidence Limits to Measurements}

IN a paper read in London by H. J. Josephs before the Institution of Electrical Engineers on January 19, the author discusses the problems involved in the application of simple tests of significance to small sets of measurements. The paper opens with an account of the $w$-test, which applies to normally distributed variables, and this is followed by a description of the $t$-test, which is of particular use in dealing with a small number of observations. A method of rapidly applying this test is given, and it is shown that if the true mean value of a physical quantity is unknown, the confidence limits to be attached to an estimated value obtained from the measurements may be determined easily. A quick method is described of estimating the standard deviation of a set of measurements, and it is shown that for very small samples the extreme-mean or median forms a good alternative to the arithmetic mean and is often easier to calculate. Pearson's $\chi^{2}$ test of goodness-of-fit is explained and illustrated, emphasis being placed on the flexible nature of this test and its relationship to the $w$-test. The elementary tests of significance described involve only a small amount of simple arithmetic, so that they enable an engineer to replace guesses or tentative estimates by well-founded probabilities, and to assess the reliability of some of his results. No mention is made in the paper of the design of large-scale experiments, for which these simple tests are of value in rapidly analysing the data obtained from preliminary trials.

\section{Earth Tremor of December 30, 1944, in Britain}

A considerable. number of personal experiences of the earth tremor have now been received, and it appears that in some places the tremor reached intensity 5 on the modified Mercalli scale (Nature, Jan. 6, p. 15). In Yorkshire, the intensity was greatest in an elongated area near Skipton, and the only damage reported in this county was one chimney which developed a crack, possibly as the result of the shock, and had to be felled. An inquiry has 